FACTA UNIVERSITATIS

Series: Physical Education and Sport, Vol. 16, No 3, 2018, pp. 557 - 567

https://doi.org/10.22190/FUPES181004050P

Research article

\title{
THE IMPACT OF AN EXPERIMENTAL DANCE PROGRAM ON THE MOTOR COORDINATION OF CHILDREN
}

\author{
UDC 793.3
}

\author{
Saša Pantelić ${ }^{1}$, Slavljub Uzunović ${ }^{1}$, Nenad Đorđević ${ }^{2}$, \\ Dejan Stošić ${ }^{3}$, Dušan Nikolić ${ }^{1}$, Danica Piršl ${ }^{1}$
}

${ }^{1}$ Faculty of Sport and Physical Education, University of Niš, Niš, Serbia

${ }^{2}$ Kindergarten „Naše dete”, Vranje, Serbia

${ }^{3}$ Faculty of Sport and Physical Education, University of Priština, Leposavić, Serbia

\begin{abstract}
This research was conducted with the purpose of determining to what extent and how a dance program affects the pre-school children's coordination. The sample comprised 65 children of a pre-school age (the control group consisted of 31 children, the experimental of 34 children), aged 6 years \pm 6 months. The experimental group performed dance activities over a period of 8 weeks (2X35 minutes each week). The control group performed regular activities in the kindergarten. The level of coordination in children was determined applying a BOT-2 test battery (the Bruininks-Oseretsky test of Motor Proficiency). By analyzing the obtained research results, a statistically significant difference was found between the dance and the control group in three variables: Jumping Jacks (0.000), Jumping in place - same sides synchronized (0.012) and Tapping feet and fingers opposite sides synchronized (0.011), respectively. Statistically significant differences between the groups indicate the positive effect of the applied dance program on the development of motor coordination in pre-school children using an experimental dance program for twelve weeks. The dance program influences the coordination of pre-school age children. The results showed that children participating in the dance program achieved better results in the studied bilateral coordination in three variables, thus recommending its application in the regular preschool curriculum.
\end{abstract}

Key words: dance, coordination-agility, pre-school age, motor skills

Received October 4, 2018 / Accepted December 24, 2018

Corresponding author: Saša Pantelić

University of Niš, Faculty of Sport and Physical Education, Čarnojevića 10a, 18000 Niš, Serbia

Phone: +381 18510900 • E-mail: spantelic2002@yahoo.com 


\section{INTRODUCTION}

The modern lifestyle, absence of physical activity and a high percentage of obesity in children and adolescents have urged scientists and sports professionals to focus their attention on solving problems in improving physical abilities related to human health at teh pre-school age, as the development of risk factors in the pre-school age is one of the leading reasons for the development of health risks in adulthood (Kouli, Roka, Mavridis, $\&$ Derri, 2009). Recently, a decrease in the level of motor abilities of children has been observed (Lenoir et al., 2014) as a result of the adverse effects of many factors, ranging from poor socio-economic problems, hypokinesia, obesity, etc.

Insufficient physical activity of pre-school age children adversely affects their general health condition, causes poor physical and mental development, as well as the development of motor skills and abilities. In children of an elderly school age, the loss of flexibility and coordination of movement have been observed (Lyulina, Zakharova, \& Vetrova, 2013). In order to mitigate these negative consequences of modern lifestyle, it is necessary to apply interventions and programs of motor development in the early periods of children's lives.

For children to be able to participate in physical activities typical of their age, it is necessary that they develop certain fundamental motor skills. One of them is general motor coordination that is the basis for carrying out motor assignments and learning new movement habits and patterns (Laukkanen, Pesola, Lyyra, Saakslahti, \& Finni, 2014). The development of this ability in this period is crucial because of its functioning in everyday life and for later physical or specific sports activities (Fischer et al., 2005). Growth and maturation of children are conditioned by genetic, hormonal and dietary influences, as well as by environmental influences. Increased physical activity is one of the environmental influences that favorably influence the growth and maturation of children. In pre-school children, motor opportunities are improved homogeneously and continuously by age and sex, and are determined by the gradual neuromuscular maturation and the development of basic models of movement (walking, running, jumping). Although maturation and growth are important for development, they are not the only ones that have a decisive influence (Venetsanou, Kambas, Sagioti, \& Giannakidou, 2009). Activities which emphasize coordination of movement are considered very important for brain development (Cotman \& Berchtold, 2002). Coordination is also a basic precondition not only for the learning, stabilization and implementation of sports skills, but also as a kind of approach to the repertoire of physical abilities, and coordination training in the pre-school age has proven to be very significant for children of that age (Kunz, 1993). Since coordination is the ability to control movements of the entire body, or parts of the locomotor apparatus, it is of the utmost importance to form a better motor base in the period of up to 7 years of age, and it is of vital importance to develop it as early as possible (Krneta et al., 2014).

In the period from the ages of three to six it is important to offer children a program of adaptive physical exercise that is conceived in the form of a game, while at the same time developing perceptual and basic motor skills and movements (Jidovtseff, Mornard, \& Delvaux, 2014). In addition to traditional forms of training and exercises for the development of coordination and other motor skills, dance as a kind of fun physical activity can be used for this purpose. Moreover, it can positively influence the socio-psychological and physical aspects of children's life. A number of studies have shown that dancers of modern and sports dance have fewer health problems (Ramel, Moritz, \& Gun-Britt, 1999; 
Alricsson \& Wemer, 2004) which is the primary task of the pre-school system. Recreational dance can improve cardiorespiratory fitness and bone health in children as well as contribute to the prevention and/or reduction of obesity. It also positively influences the improvement of the self-concept one's body image, reduces stress and, generally has a beneficial effect on mental health, develops social skills, etc. (Burkhardt \& Brennan, 2012; Malkogeorgos, Zaggelidou, \& Georgescu, 2011). Regular and intense dancing can result in a reduction in the amount of fat, the development of strength and endurance, the development of coordination and bone density as compared to non-dancing children (Yannakoulia, Keramapoulos, Tsakalakos, \& Matalas, 2000; Cieślicka, Napierała, Pilewska, \& Iermakov, 2012) which, all things considered, results in the achievement of the elite sports results. In addition to body mass and subcutaneous fat tissue, performance in dance is also affected by explosive, static and repetitive strength, coordination, balance, endurance, etc. (Viskić-Štalec, Štalec, Katić, Podvorac, \& Katović, 2007; Steinberg, Siev-Ner, Peleg, Dar, Masharawi, \& Hershkoviz, 2008; Uzunović, Kostić, \& Živković, 2010). The implementation of dance programs at the pre-school age enables one to get acquainted with various cultural features while simultaneously developing essential motor skills and abilities in the pre-school age, doing all of these through fun, dance and play (Lorenzo-Lasa, Ideishi, \& Ideishi, 2007). Depending on the type of dance, dance at that age meets most of the needs for movement and providing minimal moderate physical activity over time, which also affects the BMI (Body Mass Index) (Huang, Hogg, Zandieh, \& Bostwick, 2012) and represents an important pedagogical potential for physical training (Chuprun, 2009). Apart from the development of a feeling for rhythm, precision, coordination in space and time and expressiveness of performing movements accompanied by music, the application of dance also contributes to freedom and creativity, which is especially important for development in the pre-school age (CicovićSarajlić, Pavlović, \& Popović, 2013).

The application of a dance program at the pre-school age and the identification of the effects on coordination have not been sufficiently explored in the literature so far, and that is exactly why this problem poses the following questions for researchers: Can a specific program be applied at the pre-school age and what effect does it have on the coordination of children of that age? Congruent with these issues, the aim of this research is to determine how the dance program affects motor coordination among pre-school age children.

\section{METHODS}

\section{The sample of participants}

The sample of participants comprised preschool age children from the Pre-school institution "Naše dete" from Vranje. The total sample of participants who took part in this study were 65 boys and girls aged 6 ( \pm 6 months), out of which 34 comprised the experimental group and 31 the control group. The experimental group practiced dance elements adapted to the age of the participants, while the control group followed a regular kindergarten curriculum. The participants worked with the teachers who had successfully completed the program "Play, sing, create through a dance", accredited by the Institute for the Improvement of Education and Upbringing of the Republic of Serbia. The participants' parents, as well as the kindergarten management, had previously agreed with the research protocol, after which they signed an agreement to have the children 
participate in the research. The research was approved by the Ethical Committee of the Faculty of Sport and Physical Education, University of Niš.

\section{Sample of variables}

According to the BOT-2 test (Bruininks \& Bruininks, 2005) body coordination as a separate composite was assessed applying the following subtests: bilateral coordination and balance.

Tests for assessing bilateral coordination:

1. Touching nose with index fingers-eyes closed;

2. Jumping jacks;

3. Jumping in place-same sides synchronized;

4. Jumping in place-opposite sides synchronized;

5. Pivoting thumbs and index fingers;

6. Tapping feet and fingers-same sides synchronized;

7. Tapping feet and fingers- opposite sides synchronized.

\section{Experimental dance program}

The dance program was applied in the preschool institutions 2 times a week for 35 minutes (70 minutes a week) for twelve weeks, totaling 24 hours. All classes had a threepart structure in which various teaching contents were implemented.

The introductory part of the class consisted mainly of natural forms of movement (walking, running) accompanied with music; stylized walking with certain characteristic music, shaping exercises which are adapted to the preschool age with music and games from the preschool programs with which children had already been acquainted. The basic task of the introductory part of the class, which lasted about 7 minutes, was to prepare the participants for work in the main part of the class. However, the movements and motions which were applied also enable the work on cultivating the style of movement and spatial orientation.

The main part of the class consisted of folk games (Divna, Brankovo kolo, Kružni ples); Social dances (Boyer, Kadril, Polka, Sirtaki) and Sport Dance (English Waltz, Cha Cha).

These dances represent the basic dance content that the participants studied or perfected during 25 minutes of work. They danced to different rhythms, pace and dynamics. Choreographies were designed in such a way that they can be realized in kindergarten gyms. During the realization of dance structures, one insisted on the proper body position, the correct rhythm and style of dancing. In terms of the complexity of movement and motions, the dance is a part of the dance program "Play, sing, create through a dance" accredited by the Ministry of Education and Technological Development of the Republic of Serbia.

The basic requirement of the final part of the class was to cool down the body and make the child ready for the ongoing activities. Usually, exercises were used for breathing and relaxation, which depended on the intensity of the exercises in the main part of the class. In addition, various games of animal imitation were used, mimic representations of different professions, etc. An analysis of activities was always done at the end of the day.

Table 1 shows the structure of the experimental program in which the basic indicators of the program performed are given. 
Table 1 Structure of the experimental dance program

\begin{tabular}{|c|c|c|c|}
\hline Articulation & Contents & Frequency & $\begin{array}{c}\text { Weekly time } \\
\text { in min }\end{array}$ \\
\hline $\begin{array}{l}\text { Introductory } \\
\text { (7 min) }\end{array}$ & $\begin{array}{l}\text { - Natural forms of movement (walking, running) } \\
\text { accompanied with music, } \\
\text { - Stylized walking with certain characteristic music } \\
\text { - Shaping exercises with music } \\
\text { - Games from the preschool programs }\end{array}$ & $2 x$ & \\
\hline $\begin{array}{l}\text { Main } \\
(25 \text { min })\end{array}$ & $\begin{array}{l}\text { - Folk dances: Divna, Brankovo kolo, Kružni ples; } \\
\text { - Social dances: Bojerka, Quadrile, Polka, Sirtaki } \\
\text { - Dance Sport (English Waltz, Cha-Cha) }\end{array}$ & & \\
\hline $\begin{array}{l}\text { Final } \\
(3 \mathrm{~min})\end{array}$ & $\begin{array}{l}\text { - Breathing and relaxation exercises } \\
\text { - Analysis of activities } \\
\text { - Finalization of activities } \\
\text { - Games }\end{array}$ & & \\
\hline $\begin{array}{l}\text { Total } \\
(35 \mathrm{~min})\end{array}$ & & $2 \mathrm{x}$ a week & $70 \mathrm{~min}$ \\
\hline
\end{tabular}

\section{Statistical analysis}

The basic descriptive statistics parameters were calculated. The results of the arithmetic mean and standard deviation (Mean and SD) for all the applied variables are presented.

Differences between the initial and final measurements for the experimental and control group were determined using the Effect Size method. The size of the effects of the experimental treatment was determined by examining the differences between the initial and final measurements. The effect size (d) is classified as follows: 0.0-0.1-No Effect; 0.2-0.3-0.4 Small Effect; 0.5-0.6-0.7 Intermediate Effect; 0.8-0.9 $\geq 1.0$ Large Effect (Cohen, 1988). ANCOVA was used to determine the effects of the dance program. Data processing was performed by the SPSS 20 Statistics Program.

\section{RESULTS}

In Table 2 the basic statistical parameters for the examined coordination area at the initial and final testing are shown.

Table 2 Basic statistical parameters

\begin{tabular}{lcccc}
\hline Variables & \multicolumn{2}{c}{ Experimental group } & \multicolumn{2}{c}{ Control group } \\
\cline { 2 - 5 } & $\begin{array}{c}\text { Initial } \\
(\text { Mean } \pm \text { SD) }\end{array}$ & $\begin{array}{c}\text { Final } \\
\text { Mean } \pm \text { SD) }\end{array}$ & $\begin{array}{c}\text { Initial } \\
(\text { Mean } \pm \text { SD) }\end{array}$ & $\begin{array}{c}\text { Final } \\
\text { Mean } \pm S D)\end{array}$ \\
\hline Touching nose with index fingers-eyes closed & $2.13 \pm 1.65$ & $3.11 \pm 1.40$ & $2.32 \pm 1.55$ & $2.74 \pm 1.36$ \\
Jumping jacks & $2.08 \pm 1.01$ & $2.64 \pm 0.80$ & $1.58 \pm 1.14$ & $1.70 \pm 1.00$ \\
Jumping in place-same sides synchronized & $1.75 \pm 0.98$ & $2.24 \pm 0.88$ & $1.70 \pm 0.82$ & $1.83 \pm 0.86$ \\
Jumping in place-opposite sides synchronized & $1.13 \pm 1.03$ & $2.13 \pm 0.89$ & $0.93 \pm 0.92$ & $1.77 \pm 0.92$ \\
Pivoting thumbs and index fingers & $1.11 \pm 1.09$ & $2.28 \pm 1.07$ & $1.16 \pm 1.31$ & $2.06 \pm 1.23$ \\
Tapping feet and fingers-same sides synchronized & $3.68 \pm 0.79$ & $3.75 \pm 0.64$ & $2.41 \pm 1.50$ & $3.35 \pm 1.14$ \\
Tapping feet and fingers- opposite sides & $1.71 \pm 1.27$ & $2.28 \pm 1.51$ & $1.32 \pm 1.04$ & $1.25 \pm 1.41$ \\
synchronized & & & & \\
\hline
\end{tabular}


The results for the Mean and SD are given for the initial and final measurement of the experimental and control group. Based on the results shown, it can be concluded that there have been positive changes in all the tested variables between the initial and final measurements for both groups.

The size of the effects within each group between the initial and final measurement was determined using Cohen's effect size. The effect size is shown in Graph 1 for the control group and Graph 2 for the experimental group.

Based on the results obtained for the control group shown in Graph 1, it can be concluded that statistically significant effects between the initial and final measurement occurred in the Jumping test in place-opposite sides synchronized with Large effect size d $=.90$; Pivoting thumbs and index fingers with Intermediate effect size $\mathrm{d}=.70$; Tapping feet and fingers-same sides synchronized with Intermediate effect size $d=.52$.

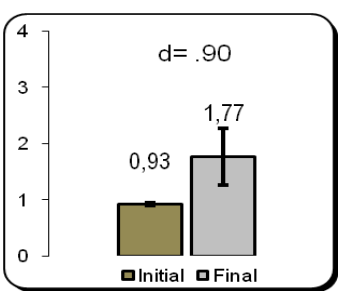

Jumping in place-opposite sides synchronized ** Large effect size

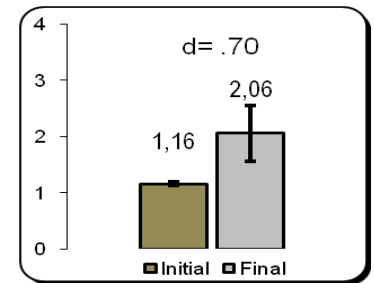

Pivoting thumbs and index fingers

* Intermediate effect size

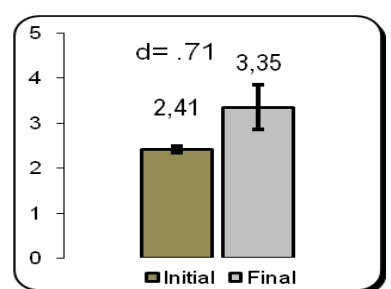

Tapping feet and fingers-same sides synchronized * Intermediate effect size

Graph. 1 Effect Size Control group

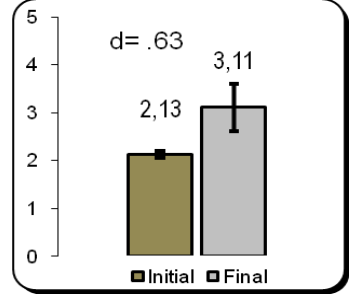

Touching nose with index fingers-eyes closed

* Intermediate effect size

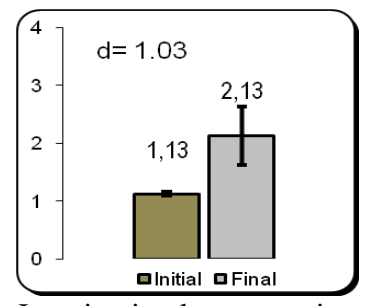

Jumping in place-opposite sides synchronized ** Large effect size

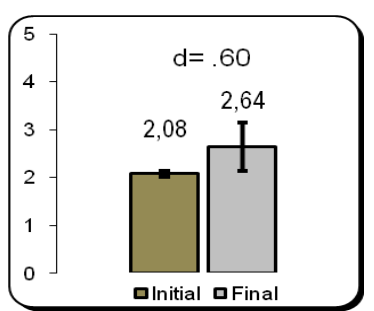

Jumping jacks

* Intermediate effect size

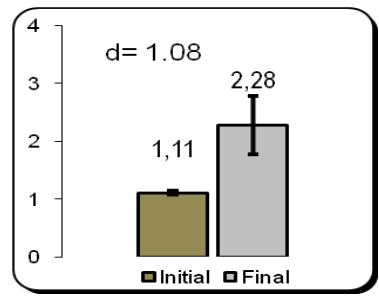

Pivoting thumbs and index fingers ** Large effect size

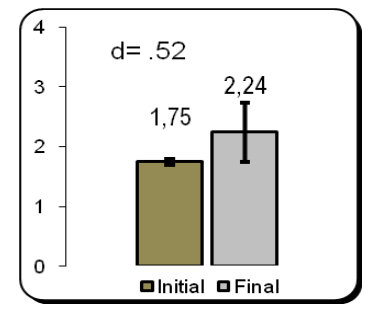

Jumping in place-same sides synchronized

* Intermediate effect size

Graph. 2 Effect Size Experimental group 
The results of Cohen's effect size are: Touching the nose with the index fingers-eyes closed 2.13/1.65, -3.11/1.40, $\mathrm{d}=.63$; Jumping jacks 2.08/1.01, $-2.64 / 0.80, \mathrm{~d}=.60$; Jumping in placesame sides synchronized $1.75 / 0.98,-2.24 / 0.88, \mathrm{~d}=.52$; Jumping in place-opposite sides synchronized 1.13/1.03, $-2.13 / 0.89, \mathrm{~d}=1.03$; Pivoting thumbs and index fingers $1,11 / 1,09$, $2,28 / 1,07, \mathrm{~d}=1.08$; Tapping feet and fingers-same sides synchronized 3.68/0.79, $-3.75 / 0.64, \mathrm{~d}=$ .09 ; Tapping feet and fingers- opposite sides synchronized 1.71/1.27, $-2.28 / 1.51, \mathrm{~d}=.41$.

Graph 2 shows the statistically significant results of the program effects between the initial and final measurement for the experimental group. The results show that the following effects were achieved: Touching the nose with the index fingers-eyes closed, Jumping jacks, Jumping in place-same sides synchronized - Intermediate effect size; Jumping in placeopposite sides synchronized, Pivoting thumbs and index fingers - Large effect size.

In order to determine the real effects of the experimental program of modified dance content on certain coordination parameters, a univariate analysis of covariance was applied and shown in Table 3 .

Table 3 Univariate analysis of covariance of the dance and control group at the final test

\begin{tabular}{|c|c|c|c|c|}
\hline & $\begin{array}{c}\text { Mean } \\
\text { Difference }\end{array}$ & $\bar{F}$ & $\begin{array}{c}\text { Sig. } \\
\text { Partial Eta } \\
\text { Squared }\end{array}$ & $\begin{array}{c}\text { Partial } \\
\text { Eta } \\
\text { Squared }\end{array}$ \\
\hline Touching nose with index fingers-eyes closed & -.454 & 2.66 & .107 & .035 \\
\hline Jumping jacks & -.692 & 15.47 & .000 & .175 \\
\hline Jumping in place-same sides synchronized & -.375 & 6.70 & .012 & .084 \\
\hline Jumping in place-opposite sides synchronized & -.279 & 2.12 & .149 & .028 \\
\hline Pivoting thumbs and index fingers & -.248 & 1.11 & .295 & .015 \\
\hline Tapping feet and fingers-same sides synchronized & .146 & 0.54 & .463 & .007 \\
\hline Tapping feet and fingers- opposite sides synchronized & -.754 & 6.84 & .011 & .086 \\
\hline
\end{tabular}

On the basis of the obtained results, it can be concluded that there were statistically significant effects in three out of the seven tested variables in favor of the experimental group: Jumping jacks, $\mathrm{F}=15.47, \mathrm{p}=.000$; Jumping in place-same sides synchronized, $\mathrm{F}=$ $6.70, p=.012$; Tapping feet and fingers- opposite sides synchronized, $F=6.84, p=.011$.

\section{DISCUSSION}

The greater the motor complexity of the activity, the greater the importance of training co-ordination abilities. Coordination skills are of great importance in those sports that require a high level of technical suppleness, such as sports and rhythmic gymnastics, artistic skating or dancing. The results of the conducted research showed that the implemented experimental dance program achieved statistically significant effects on the experimental group of participants.

The experimental program contains a wide range of movements and rhythm movements, which has, presumably, influenced changes in coordination indicators after a twelve-week exercise program. The application of dance programs at the preschool age can improve the motor efficiency and skills of children. This was also demonstrated by a survey conducted on a sample of 36 boys and 30 girls, aged 4 to 6 , for 20 weeks using traditional Greek 
dances (Venetsanou \& Kambas, 2010). Similar results were obtained by applying an accredited dance program on a sample of 36 boys aged 6 (Uzunović, Veselinović, \& Stojanović, 2011).

The results showed that the applied dance program influenced the changes of all the examined variables and led to the transformation of all motor abilities during the 3 month program. By equating the results on the initial measurement, applying the univariate analysis of covariance, statistically significant effects were found on three out of seven applied tests. National games can primarily develop motor skills of the lower part of the body, especially the rhythm of the legs. Elements of the technique of social dance can influence the postural status of children, but also the expression of rhythmic structures. We believe that the elements of the technique of sports dance, applied in different rhythms, have greatly contributed to the quality of movement in children. All these three dance segments together are assumed to have contributed to the qualitative and quantitative changes in coordination on the test sample. The available previously carried out research corroborates this fact. One of the main determinants of achievements in the motor domain is coordination, and precisely for this reason the development of coordination abilities in childhood is important (Busch \& Strauss, 2005).

In a 12-week study, positive results were recorded in favor of the group that implemented the dance program, and positive results were also obtained for the 8-week program (Shick, Stoner, \& Jette, 1983). In this research, the authors applied an unknown balance test on a group of advanced dancers and a group of beginner dancers. The results obtained showed that advanced dancers achieved significantly better results than beginner dancers.

When comparing the results in the research we conducted, we obtained that the experimental group showed better results than the control group at the age of 6-7. Similar results were found in the research by authors who researched the influence of dance content on the motor skills of boys and girls aged 6-7 (Kostić, Miletić, Jocić, \& Uzunović, 2002), as well as a survey of a sample of 85 children aged 8 , where improvement of the coordination variables in favour of the experimental group was the result of the implementation of the Polish social dance program (Dorota, 2008).

The results obtained suggest that the length of the implementation of the dance program would considerably improve and develop the biomotor abilities that were observed in children, and it is assumed that children with better biomotor abilities would be better in dance activities. This assertion is confirmed by a study on a sample of 80 female girls aged 6 years \pm 6 months, which showed that there were statistically significant relationships between the quality of the performance of dance structures and motor coordination (Stanišić, Kostić, Uzunović, \& Marković, 2008).

Similar results were found in children with less developed coordination (Scott, 2010). Such results confirm the results of various authors who emphasized the importance and advantages of performing organized physical activity, and in particular the implementation of dance, for improving the morphological and motor characteristics of children, especially pre-school and young school age children (Blažević, Katić, \& Zagorac, 2002; Madić, Mikalački, \& Popović, 2008; Madić, Popović \& Kaličanin, 2009). Some authors have by studying the transformational processes of some motor skills, obtained results which show that the greatest contribution to the effects of modern sports dance training provide variables for estimating speed, strength, and coordination (Uzunović et al., 2010; Srhoj, Katić, \& Kaliterna, 2006). 
It is significant to note that dance is an irreplaceable educational method in kinesiological education (Srhoj et al., 2006). The authors have paid special attention in their scientific research to the analysis of coordination and dance. Research studies have already mentioned that, in addition to other abilities, they have also dealt with the ability of coordination and its relation to dance (Srhoj et al., 2006). Coordination abilities are also an important predictor for success in the performance of sport dance (Uzunović, Kostić, Zagorc, Oreb, \& Jocić, 2005). The authors conclude that based on coordination abilities, success can be predicted in competitions in standard sports dancing, 30\% of a male dancer sample and $40 \%$ of a female dancer sample.

Some additional research should give an answer as to how much the experimental group would produce better results as compared to the control group if the dance program was realized during the whole school year.

\section{CONCLUSION}

A dance program influences the coordination of pre-school aged children. The results showed that children who participated in the dance program had better results in testing motor coordination in three out of the seven tested variables. Investigation of the motor skills should begin as early as possible in order to improve coordination in children, which in turn will have a positive impact on the expression of maximum motor skills.

\section{REFERENCES}

Alricsson, M., \& Wemer, S. (2004). The effect of pre-season dance training on physical indices and back pain in elite cross-country skiers. Britich Journal of Sports Medicine, 38(2), 148-153.

Blažević, S., Katić, R., \& Zagorac, N. (2002). Morphological structure on leg explosiveness under a systematic treatment in children aged 7-9. In D. Milanović, \& F. Prot (Eds.), Kinesiology new perspectives, (pp. 98101). Zagreb: Faculty of Kinesiology, University of Zagreb.

Bruininks, R., \& Bruininks, B. (2005). Bruininks-Oseretsky Test of motor proficiency (2nd ed.). Minneapolis, MN: NCS Pearson.

Burkhardt, J., \& Brennan, C. (2012). The effects of recreational dance interventions on the health and wellbeing of children and young people. A systematic review. Arts \& Health: An International Journal for Research, Policy and practice, 4(2), 148-161.

Busch, D., \& Strauss, B. (2005). Qualitative differences in performing coordination tasks. Measurement in Physical Education and Exercise Science, 93 (3), 161-180.

Chuprun, N. (2009). Morphofunctional readiness of junior school boys to forming basic components of coordinating capabilities in the process of teaching dancing exercises. Pedagogics, Physchology, MedicalBiological Problems of Physical Training and Sports, 5, 275-278.

Cicović-Sarajlić, D., Pavlović, B., \& Popović, B. (2013). Dancing as an expression of children's creativity in music culture teaching and physical education. Activities in Physical Education and Sport, 3(1), 77-78.

Cieślicka, M., Napierała, M., Pilewska, W., \& Iermakov, S. (2012). Status of morphological and motor skills of girls participating in modern dance classes. Pedagogics, Psychology, Medical-Biological Problems of Physical Training and Sports, 10, 96-104.

Cohen, J. (1988). Statistical power analysis for the behavioral sciences (2. Auflage). Hillsdale, NJ: Erlbaum.

Cotman, C.W., \& Berchtold, N. C. (2002). Exercise: a behavioral intervention to enhance brain health and plasticity. Trends in Neurosciences, 25(6), 295-301.

Dorota, R. (2008). Level of coordination motor abilities in children practicing Polish social dances. Polish Journal of Sport \& Tourism, 15 (1/2), 37-39.

Fischer, A., Reilly, J., Kelly, L., Montgomery, C., Williamson, A., Paton, J., \& Grant, S. (2005). Fundamental movement skills and habitual physical activity in young children. Medicine and Science in Sports and Exercise, 37, 684-688 
Huang, S.Y., Hogg, J., Zandieh, S., \& Bostwick, S.B. (2012). A ballroom dance classroom program promotes moderate to vigorious physical activity in elementary school children. American Journal of Health Promotion, 26(3), 160-165.

Jidovtseff, B., Mornard, M., \& Delvaux, A. (2014). Sport classes at the CEReKi: A complete day for preschool fundamental motor development. Science \& Sports, 29, S13

Kostić, R.M., Miletić, Đ., Jocić, D.J., \& Uzunović, S. (2002). Influence of dance structures on motor abilities in preschool age children. Facta Universitatis Series Physical Education and Sport, 1(9), 83-90.

Kouli, O., Roka, S., Mavridis, G., \& Derri, V. (2009). The effects of the aerobic program on health - related fitness and intrinsic motivation in elementary school pupils. Studies in Physical Culture and Tourism, 16(3), 301-306.

Krneta, Z., Drid, P., Jakšić, D., Bala, G., Stojanović, M., \& Ostojić, S. (2014). Effects of kinesiological activity on preschool children's motor abilities. Science \& Sports, 29, S48.

Kunz, T. (1993). Weniger unfaelle durch bewegung (Less accidents by movement). Schorndorf: Hofmann. In German

Laukkanen, A., Pesola, A.J., Lyyra, N., Saakslahti, A., \& Finni, T. (2014). Trajectories of motor coordination in 4-7 years-old children: A latent growth curve analysis. Science \& Sports, 29, S22-S23.

Lenoir, M., Bardid, F., Huyben, F., Deconinck, F., Seghers, J. \& De Marelaer, K. (2014). The effectiveness of "Multimove": A fundamental motor skill intervention for typically developing young children. Science \& Sports, 29, S49.

Lorenzo-Lasa, R., Ideishi, R.I., \& Ideishi, S.K. (2007). Facilitating preschool learning and movement through dance. Early Childhood Education Journal, 35(1), 25-31.

Lyulina, N.V., Zakharova, L.V., \& Vetrova, I.V. (2013). Effect of complex acrobatic elements in the development of physical skills of preschool children. Physical Education of Students, 4, 59-62.

Madić, D., Mikalački, M., \& Popović, B. (2008). Effects of the traditional and modern approach to physical education on obesity of girls at younger school age. International Symposium Research and Education in Innovation Era, (pp. 577-582). Arad: University „Aurel Vlaicu“.

Madić, D., Popović, B. \& Kaličanin, N. (2009). Anthropometric characteristics of girls included in program of development gymnastics. Glasnik Antropološkog Društva Srbije, 44, 79-86.

Malkogeorgos, A., Zaggelidou, E., \& Georgescu, L. (2011). The effects of dance practice on health. Asian Journal of Exercise \& Sports Science, 8(1), 100-112.

Ramel, E., Moritz, U., \& Gun-Britt, J. (1999). Validation of a pain Questionnaire (SEFIP) for dancers with a specially created battery. Medical Problems of Performing Artists, 14(4), 196-203.

Scott, J.L. (2010). The effect of a metronome-based coordination training programme on the fundamental gross motor skills of children with motor development delays (Doctoral dissertation). Stellenbosch: University of Stellenbosch.

Shick, J., Stoner, L.J., \& Jette, N. (1983). Relationship between modern-dance experience and balancing performance. Research Quarterly for Exercise \& Sport, 54(1), 79-82.

Srhoj, L., Katić, R., \& Kaliterna, A. (2006). Motor abilities in dance structure performance in female students. Collegium Antropologicum, 30(2), 335-341.

Stanišić, I., Kostić, R., Uzunović, S., \& Marković, J. (2008). The significance of the relations between the quality of the performance of dance structures and the motor coordination skills of preschool children. Facta Universitatis Series Physical Education and Sport, 6(2), 125-133.

Steinberg, N., Siev-Ner, I., Peleg, S., Dar, G., Masharawi, Y., \& Hershkoviz, I. (2008). Growth and development of female dancers aged 8-16 years. American Journal of Human Biology, 20 (3), 299-307.

Uzunović, S., Veselinović, N., \& Stojanović, J. (2011). Effect of children's dance program „Dance, sing, create through dance" on mobility capabilities of preschool boys in Niš. Research in Kinesiology, 39(1), 103-106.

Uzunović, S., Kostić, R., \& Živković, D. (2010). Effects of two different programs of modern sports dancing on motor coordination, strength, and speed. Medical Problems of Performing Artists, 25(3), 102-109.

Uzunović, S., Kostić, R., Zagorc, M., Oreb, G., \& Jocić, D. (2005). The effect of coordination skills on the success in standard sports dancing. European College of Sport Science, 10th Annual Congress, Belgrade, (pp. 32).

Venetsanou, D., \& Kambas, A. (2010). How can a tradicional Greek dances programme affect the motor proficiency of pre-school children?. Research in Dance Education, 5(2), 127-138.

Venetsanou, F., Kambas, A., Sagioti, E., \& Giannakidou, D. (2009). Effect of an exercise program emphasizing coordination on preschoolers' motor proficiency. European Psychomotricity Journal, 2(1), 46-55.

Viskić-Štalec, N., Štalec, J., Katić, R., Podvorac Đ., \& Katović, D. (2007). The impact of dance-aerobics training on the morpho-motor status in female high-schoolers. Collegium Antropologicum, 31(1), 259-266.

Yannakoulia, M., Keramapoulos, A., Tsakalakos, N., \& Matalas, A.L. (2000). Body composition in dancers: the bioelectrical impedance method. Medicine \& Science in Sports \& Exercise, 32(1), 228-234. 


\section{UTICAJ EKSPERIMENTALNOG PLESNOG PROGRAMA NA KOORDINACIJU DECE}

Ovo istraživanje je sprovedeno sa ciljem da se utvrdi u kojoj meri i kako plesni program utiče na koordinaciju predškolske dece. Uzorak je obuhvatio 65-toro dece predškolskog uzrasta (kontrolna grupa se sastojala od 31-nog, eksperimentalna od 34-voro dece), starosti 6 godina \pm 6 meseci. Eksperimentalna grupa je sprovodila plesne aktivnosti u periodu od 8 nedelja $(2 \times 35$ minuta svake nedelje). Kontrolna grupa je obavljala redovne aktivnosti u vrtiću. Nivo koordinacije kod dece je utvrđen primenom BOT-2 baterije testova (the Bruininks-Oseretsky test of Motor Proficiency). Analizom dobijenih rezultata istraživanja utvrđena je statistički značajna razlika između plesne $i$ kontrolne grupe u tri varijable: lepeza (Jumping Jacks (0.000)), skakanje u mestu unilateralno sinhronizovano (Jumping in place - same sides synchronized (0.012)) $i$ taping stopalima i prstima sinhronizovano sa suprotne strane (Tapping feet and fingers - opposite sides synchronized (0.011)), tim redosledom. Statistički značajne razlike između grupa ukazuju na pozitivan efekat primenjenog plesnog programa na razvoj koordinacije kod predškolske dece koristeći eksperimentalni plesni program. Program plesa utiče na koordinaciju dece predškolskog uzrasta. Rezultati su pokazali da su deca koja učestvuju u plesnom programu ostvarila bolje rezultate u proučavanoj bilateralnoj koordinaciji u tri varijable, pa se stoga preporučuje primena programa plesa u redovnom predškolskom kurikulumu.

Ključne reči: ples, koordinacija-agilnost, predškolski uzrast, motoričke sposobnosti 